See discussions, stats, and author profiles for this publication at: https://www.researchgate.net/publication/305308573

\title{
Effects of area and available energy on fish assemblages of tropical streams
}

Article in Marine and Freshwater Research · July 2016

DOI: 10.1071/MF15431

CITATION

1

3 authors:

Bruno Goncalves

São Paulo State University

31 PUBLICATIONS 57 CITATIONS

SEE PROFILE

(8)

Rodrigo Assis Carvalho

Universidade Estadual de Goiás

24 PUBLICATIONS 179 CITATIONS

SEE PROFILE
READS

164

Francisco Leonardo Tejerina-Garro

Pontifícia Universidade Católica de Goiás (PUC Goiás)

65 PUBLICATIONS 630 CITATIONS

SEE PROFILE

Some of the authors of this publication are also working on these related projects:

FIRE EFECT ON THE SEASONAL FOREST STRUCTURE IN THE CERRADO BIOME View project

Biodiversity Conservation of Forest Fragments in the Fernao Dias APA View project 


\title{
Effects of area and available energy on fish assemblages of tropical streams
}

\author{
Bruno Bastos Gonçalves ${ }^{\mathrm{A}}$, Francisco Leonardo Tejerina-Garro ${ }^{\mathrm{B}, \mathrm{C}}$ \\ and Rodrigo Assis de Carvalho ${ }^{\mathrm{D}, \mathrm{E}}$ \\ A Programa de pós-graduação em Aquicultura, Jaboticabal, Departamento de Fisiologia, \\ Instituto de Biociências, Universidade Estadual Paulista 'Júlio de Mesquita Filho' (UNESP), \\ Distrito de Rubião Junior, s/n, 18618970, Botucatu, SP, Brazil. \\ ${ }^{B}$ Centro de Biologia Aquática, Departamento de Ciências Biológicas, PUC Goiás, Campus II, \\ Avenida Engler s/n, 74885460, Goiânia, GO, Brazil. \\ ${ }^{C}$ Programa de Pós-graduação em Sociedade, Tecnologia e Meio Ambiente, UniEVANGÉLICA, \\ Avenida Universitária quilômetro 3.5, Cidade Universitária, 75083515, Anápolis, GO, Brazil. \\ DUniversidade Estadual de Goiás (UEG), Programa de Pós-Graduação em Recursos Naturais do \\ Cerrado (RENAC), Câmpus de Ciências Exatas e Tecnológicas,Henrique Santillo, BR 153, \\ number 3105 Fazenda Barreiro do Meio, 75132400, Anápolis, GO, Brazil. \\ ${ }^{\mathrm{E}}$ Corresponding author. Email: decarvalho.ra@gmail.com
}

\begin{abstract}
A central issue in fish community ecology is to understand how the size of the drainage area and the available energy influence fish species diversity and their spatial distribution. In the present study, we tested whether the speciesarea relationship (represented by drainage area) and species-energy association (represented by algal biomass and organic matter) drive taxonomic and functional richness in a regional scale. The results indicated that fish assemblages of the two tropical neighbouring basins sampled responded differently to the size of drainage area. Whereas taxonomic richness was influenced by the size of the drainage area in Tocantins River basin streams, it was not affected in Araguaia River basin streams. Both taxonomic richness and functional richness of the fish assemblages were affected by available energy in the system. A possible explanation for these different responses is related to local conditions, such as the percentage of natural vegetation cover encountered in each basin.
\end{abstract}

Additional keywords: algal biomass, land use, organic matter, vegetation cover.

Received 13 November 2015, accepted 16 May 2016, published online 14 July 2016

\section{Introduction}

Fish species represent $30 \%$ of all known vertebrate species on Earth (Strayer and Dudgeon 2010). Considering the totality of fish species described, $\sim 40 \%$ of them are encountered in freshwater ecosystems (Dudgeon et al. 2006). With human activities pressuring these systems and leading to unprecedented levels of extinction (Dudgeon et al. 2006; Vörösmarty et al. 2010), there is an urgent need to provide protection for freshwater habitats. However, the development of conservation actions is directly dependent on our knowledge on how species diversity is distributed along space, and which factors affect this distribution.

In the past decade, the number of studies in the Neotropical region focusing on the distribution patterns of fish species diversity in local and regional scales has increased (Bistoni and Hued 2002; Hoeinghaus et al. 2004; Fialho et al. 2007; Súarez et al. 2011; Santana et al. 2014; Carvalho and TejerinaGarro 2015; Teresa et al. 2015). The main results of these studies have shown that fish species diversity is associated to different factors, such as variation in the longitudinal gradient of streams coupled with environmental variables, stream features (e.g. stream order), position in the river channel and changes from dry to rainy seasons (seasonality) and the degree of deforestation. Despite such recent effort, only few studies have investigated the patters of fish species distribution at a large scale in the Neotropical region (Súarez et al. 2011). This situation concerns freshwater-fish conservation because it has been estimated that more than 4000-6000 species are present in the Neotropical region (Reis et al. 2003; Lévêque et al. 2008; Albert and Reis 2011).

According to classical studies, the following hypotheses were already proposed to explain gradients in species richness: (1) species-area relationship (MacArthur and Wilson 1967); (2) species-energy relationship (Wright 1983); and (3) historical hypothesis (Whittaker et al. 2001). The hypothesis of speciesarea relationship predicts that larger areas will harbour a higher 
number of species than do smaller areas because they are expected to (1) have more habitat heterogeneity and food resources availability (Williamson 1988), (2) reduce the probability of extinction because larger areas have more resources available and tend to support more individuals (MacArthur and Wilson 1967) and (3) present higher speciation rates, given their higher habitat heterogeneity (Losos and Schluter 2000). The species-energy hypothesis predicts that species diversity is a response to energy availability in the system. For example, local and regional fish species diversity may respond to variations in the input of energy along the longitudinal gradient of streams, as proposed by the river-continuum concept (Vannote et al. 1980). Finally, the historical hypothesis predicts that species diversity is a consequence of the potential of system recolonisation and the maturation of such systems after glaciation. At the global scale, patterns of riverine fish diversity are explained by two major factors, namely, energy availability and habitat heterogeneity (Guégan et al. 1998).

Here, our main goal relies on the study of patterns of taxonomic richness (species richness) and functional richness (species richness by trophic group) of tropical freshwater fish assemblages. We tested whether the species-area relationship (represented by drainage area) and species-energy association (represented by algal biomass and organic matter) drive taxonomic and functional richness of fish assemblages in a regional scale; that is, we expect that both taxonomic and functional richness of fish assemblages will be positively related to the increase of drainage area and available energy in the system.

\section{Materials and methods}

\section{Study area}

The study area is located in the Goiás State, central Brazil. The Tocantins-Araguaia basin is one of the most developed watersheds of the Amazonian province (Ribeiro et al. 1995; Lévêque et al. 2008). The Tocantins-Araguaia basin has an estimated size of $767000 \mathrm{~km}^{2}$ and it presents a mean annual discharge of $11000 \mathrm{~m}^{3} \mathrm{~s}^{-1}$ (Costa et al. 2003). Our study area is represented by the upper section of the basin that is located in the Goiás State, central Brazil. In this region, the drainage areas of its main tributaries (Tocantins and Araguaia rivers) are geographically separated by mountain chains, such as Serra do Caiapó and Serra dos Pirineus (Tejerina-Garro 2008), and they form two distinct basins, namely, Araguaia River basin (hereafter Araguaia basin) and Tocantins River basin (hereafter Tocantins basin). Both basins have a well-defined dry (May-October) and wet (NovemberApril) season (Albrecht and Pellegrini-Caramaschi 2003; Quesada et al. 2004). The original vegetation cover formed mainly by cerrado phytophysiognomies was altered by human occupation (mainly agriculture and cattle-ranching activities), which placed the cerradoas as the second-most modified Brazilian biome (PMDBBS 2016). However, deforestation is not the same in the two basins because differences in topography differently favour the earlier mentioned activities, that is, the Araguaia basin has plane low-altitude areas favourable to agriculture and cattleranching, whereas the Tocantins basin has scarped areas with steep slopes that hamper these activities (de Oliveira 2014), being allied to extended areas for conservation or sustainable use (Galinkin 2003). This situation affects also the riparian vegetation,
Table 1. Description of the predominant type of riparian vegetation along the stream bank of stretches sampled in the Araguaia and Tocantins basins

Stream number follows those displayed in Fig. 1

\begin{tabular}{|c|c|c|c|}
\hline \multirow[t]{2}{*}{ Basin } & \multirow[t]{2}{*}{ Stream number } & \multicolumn{2}{|c|}{ Riparian vegetation by stream bank } \\
\hline & & Right & Left \\
\hline \multirow[t]{11}{*}{ Araguaia } & 1 & Shrubs & Grasses and shrubs \\
\hline & 2 & No vegetation & No vegetation \\
\hline & 3 & Shrubs and trees & Shrub \\
\hline & 4 & Grasses and shrubs & Grasses and shrubs \\
\hline & 5 & No vegetation & No vegetation \\
\hline & 6 & No vegetation & No vegetation \\
\hline & 7 & Shrubs and trees & Shrubs and trees \\
\hline & 8 & No vegetation & No vegetation \\
\hline & 9 & Shrubs & Shrubs \\
\hline & 10 & No vegetation & No vegetation \\
\hline & 11 & Shrubs and trees & Shrubs \\
\hline \multirow[t]{10}{*}{ Tocantins } & 12 & Shrubs & Shrubs \\
\hline & 13 & Shrubs & Shrubs and trees \\
\hline & 14 & Shrubs and trees & Shrubs and trees \\
\hline & 15 & Shrubs & Shrubs and trees \\
\hline & 16 & Shrubs and trees & Shrubs and trees \\
\hline & 17 & Grasses & Shrubs \\
\hline & 18 & No vegetation & No vegetation \\
\hline & 19 & Trees & Trees \\
\hline & 20 & Shrubs & Shrubs \\
\hline & 21 & Grasses & Grasses \\
\hline
\end{tabular}

expressed by the absence of this vegetation along many of the stream stretches sampled in the Araguaia basin in relation to those of the Tocantins basin (Table 1).

\section{Sampling protocols}

During the dry season (March to September 2008), we sampled 21 watercourses, 11 being located in the Araguaia River basin and 10 in the Tocantins River basin (Fig. 1). All watercourses sampled belong to 1 st or 2 nd order, according to the classification of Strahler (1957). In each watercourse, we delimited and georeferenced (GPS eTrex, Garmin, USA) a stretch of $50 \mathrm{~m}$. Along the stretch, five transects of $10 \mathrm{~m}$ each were demarcated and both biotic (fish) and abiotic (environmental variables) data were collected.

Fish species were collected using a seine net $(4 \times 1.3 \mathrm{~m}$; $0.1 \mathrm{~mm}$ between knots) along the stretch, which was covered 10 times. Fish was fixed with formalin and conserved in containers holding formaldehyde at $20 \%$. In the laboratory of the Centro de Biologia Aquática, PUC Goiás, fish were identified through the use of identification keys (Planquette et al. 1996; Santos et al. 2004; Melo et al. 2005), measured (mm) and weighed $(\mathrm{g})$. Specimens of each species were sent to the Laboratory of Ichthyology of the Pontifícia Universidade Católica do Rio Grande do Sul to confirm identification. The trophic guild of each species was determined according to the online database FishBase (R. Froese and D. Pauly, see htpp://www.fishbase.org, accessed 10 September 2015).

For the first, third and fifth transects of each stretch, we used a quadrat $(0.5 \times 0.5 \mathrm{~m})$ to collect vegetable organic matter (leaves, branches, fruits, seeds; hereafter, organic matter, OM). The OM 


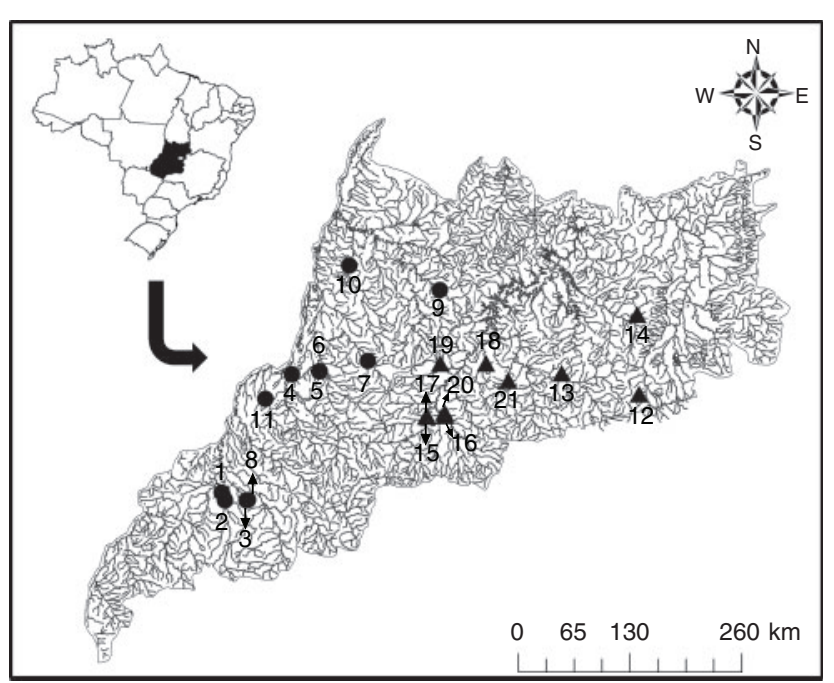

Fig. 1. Location of the watercourses sampled in the Araguaia (circles) and Tocantins (triangles) River basins in the Goiás State, central Brazil.

was then dried in the laboratory in an oven for $24 \mathrm{~h}$ at $105^{\circ} \mathrm{C}$, weighed and calcined (furnace) at $550^{\circ} \mathrm{C}$, and weighed again (Silva et al. 1999). The final OM weight was standardised by dividing it by the quadrat area, and expressed in grams per square metre.

The algal biomass $(\mathrm{AB})$ was determined through the extraction and measurement of the chlorophyll- $a$. For that, at the first and the fifth transects of each stretch, the water along the watercourse bank was pumped during $5 \mathrm{~min}$ (water pump, P835, Stihl, Brazil), filtered by a plankton net $(20-\mu \mathrm{m}$ mesh) and stored in an amber bottle $(1 \mathrm{~L})$ containing $1 \mathrm{~mL}$ of magnesium carbonate. In the laboratory, the sample was filtered (Millipore $0.45-\mu \mathrm{m}$ filter, $25-\mathrm{mm}$ diameter), the chlorophyll was extracted with methanol and the concentration determined by a spectrophotometer (Cary, 50 CONC-UV, Varian, USA) following the protocol of Wetzel and Likens (1991). Algal biomass was expressed in milligrams per litre.

The measurements of the drainage area (DA) and the total percentage of vegetation cover (TPVC) of each watercourse were performed in the software ArcGIS (ESRI, USA) using hydrological and land-use maps (scale $1: 250000$ ) available on the website of the Sistema Estadual de Estatística e Informações Geográficas do Estado de Goiás (SIEG, see http://www.sieg.go. gov.br/, accessed 21 October 2015). We measured DA as the area $\left(\mathrm{km}^{2}\right)$ between the headwater of the watercourse and the location of the stretch sampled, respecting the boundaries of the basin. We classified land use into the following five categories: agriculture, urban areas, cerrado sensu stricto, forest (cerradão, mataseca, riparian forest, gallery forest) and pasture, all of them measured in square kilometres. We obtained TPVC accordingly to the following formula:

$$
\% \mathrm{TPVC}=(\mathrm{CA}+\mathrm{FA}) / \mathrm{DA} \times 100
$$

where $\% \mathrm{TPVC}$ is the total percentage of vegetation cover, $\mathrm{CA}$ is the total cerrado area, FA is the total forest area and DA is the drainage area.

\section{Statistical analysis}

Separately, we performed two multiple regressions by basin (Araguaia and Tocantins), considering taxonomic richness (S) or functional richness (richness of the trophic guild) as response variables and area (DA) and available energy (AB and $\mathrm{OM})$ as explanatory variables. We tested the principle of normality using a Shapiro-Wilk test and, whenever necessary, we transformed the data with a logarithm $\left(\log _{10+1}\right)$.

If the multiple regression analysis was statistically significant, we performed an analysis of covariance (ANCOVA) between residuals (dependent variable) and two covariates represented by the basins (Araguaia and Tocantins; categorical predictor variable) and the total percentage of vegetation cover (TPVC; continuous predictor variable). All analyses were performed using the software STATISTICA 8.0 (StatSoft, Brazil).

\section{Results}

We found 4093 fish specimens from 5 orders, 15 families and 62 species (Table 2). We collected 56 species from eight trophic guilds and 35 species from six trophic guilds in watercourses of Araguaia and Tocantins River basins respectively (Table 2).

\section{Taxonomic (S) and functional richness (trophic-guild richness)}

The multiple regression analysis indicated that the relationship between the taxonomic or functional richness of fish assemblages and the factor area (DA) and available energy (OM and $\mathrm{AB}$ ) did not occur in a similar way in the two watercourses grouped by basin (Araguaia and Tocantins).

We did not find significant relationships between taxonomic or functional fish richness and area and available energy in the watercourses of the Araguaia River basin (Table 3). For the Tocantins River basin, we found a positive relationship between taxonomic richness and area and available energy $(P=0.007$; Table 3), that is, taxonomic richness increased as a function of $\mathrm{DA}$ and available energy (OM and $\mathrm{AB})$. When we did not consider the $\mathrm{DA}, \mathrm{AB}$ was negatively related to taxonomic richness $(P=0.023$; Table 3$)$, that is, taxonomic richness decreased when $\mathrm{AB}$ increased. The functional richness was positively related to $\mathrm{OM}$ and $\mathrm{AB}(P=0.023$; Table 3$)$, meaning that, an increase in functional richness was due to an increase in $\mathrm{OM}$ and $\mathrm{AB}$ (available energy) in the system.

The ANCOVA analysis indicated that the residuals of the significant relationships described above are not related to the covariates considered (basin and TPVC; Table 4), except for the taxonomic richness-available energy relationship, which is related to the TPVC (Table 4). It means that the relationship increases (the residual tends to diminish) when the TPVC increases, independently of the basin (Fig. 2).

\section{Discussion}

Generally, larger areas are expected to harbour a higher number of species; therefore, species richness is expected to grow as the size of an area increases (Arrhenius 1921; MacArthur and Wilson 1967). Evidence of this positive relationship in aquatic systems has been described at smaller (Eadie et al. 1986; Chittaro 2002) and larger (Watters 1992; Guégan et al. 1998; 
Table 2. Fish species sampled in the watercourses of the Araguaia and Tocantins basins, central Brazil, in the dry season of 2008 The trophic guild is indicated for each species.

\begin{tabular}{|c|c|c|c|c|c|c|c|}
\hline \multirow[t]{2}{*}{ Species } & \multirow[t]{2}{*}{ Trophic guild } & \multicolumn{2}{|c|}{ Basin } & \multirow[t]{2}{*}{ Species } & \multirow[t]{2}{*}{ Trophic guild } & \multicolumn{2}{|c|}{ Basin } \\
\hline & & Araguaia & Tocantins & & & Araguaia & Tocantins \\
\hline Characiformes & & & & Characiformes (cont.) & & & \\
\hline Anostomidae & & & & Steindachnerina sp. & Detritivorous & $\mathrm{X}$ & \\
\hline Leporinus friderici & Omnivorous & $\mathrm{X}$ & $\mathrm{X}$ & Steindachnerina sp. 2 & Detritivorous & $\mathrm{X}$ & \\
\hline Characidae & & & & Erythrinidae & & & \\
\hline Astyanax abramis & Omnivorous & $\mathrm{X}$ & & Hoplerithrinus unitaeniatus & Omnivorous & $\mathrm{X}$ & \\
\hline Astyanax fasciatus & Omnivorous & $\mathrm{X}$ & $\mathrm{X}$ & Hoplias malabaricus & Piscivorous & $\mathrm{X}$ & $\mathrm{X}$ \\
\hline Astyanax sp. 1 & Omnivorous & $\mathrm{X}$ & $\mathrm{X}$ & Parodontidae & & & \\
\hline Astyanax sp. 2 & Omnivorous & $\mathrm{X}$ & $\mathrm{X}$ & Apareiodon sp. & Algivorous & $\mathrm{X}$ & \\
\hline Astyanax sp. 3 & Omnivorous & $\mathrm{X}$ & $\mathrm{X}$ & Apareiodon sp. 2 & Algivorous & & $\mathrm{X}$ \\
\hline Bryconamericus sp. 2 & Omnivorous & & $\mathrm{X}$ & Cyprinodontiformes & & & \\
\hline Bryconamericus sp. 3 & Omnivorous & & $\mathrm{X}$ & Poeciliidae & & & \\
\hline Bryconops caudomaculatus & Insectivorous & $\mathrm{X}$ & $\mathrm{X}$ & Pamphorichthys sp. & Invertivore & $\mathrm{X}$ & $\mathrm{X}$ \\
\hline Charaxgibbosus & Piscivorous & $X$ & & Gymnotiformes & & & \\
\hline Creagrutos sp. & Insectivorous & $\mathrm{X}$ & $\mathrm{X}$ & Sternopygidae & & & \\
\hline Galeocharaxgulo & Piscivorous & $\mathrm{X}$ & & Eigenmannia virescens & Insectivorous & $\mathrm{X}$ & $\mathrm{X}$ \\
\hline Hemigrammus sp. & Insectivorous & $X$ & $\mathrm{X}$ & Perciformes & & & \\
\hline Hyphessobrycon sp. & Insectivorous & $\mathrm{X}$ & $\mathrm{X}$ & Cichlidae & & & \\
\hline Iguanodectes spilurus & Omnivorous & $\mathrm{X}$ & & Aequidens tetramerus & Omnivorous & $\mathrm{X}$ & $\mathrm{X}$ \\
\hline Jupiaba cf. polylepis & Omnivorous & $\mathrm{X}$ & $\mathrm{X}$ & Apistograma sp. & Omnivorous & $\mathrm{X}$ & $\mathrm{X}$ \\
\hline Knodus sp. & Omnivorous & $\mathrm{X}$ & $\mathrm{X}$ & Retroculus lapidifer & Insectivorous & $\mathrm{X}$ & \\
\hline Moenkhausia collettii & Omnivorous & $\mathrm{X}$ & & Satanoperca acuticeps & Omnivorous & $\mathrm{X}$ & \\
\hline Moenkhausia dichoura & Omnivorous & $X$ & & Siluriformes & & & \\
\hline Moenkhausia lepidura & Omnivorous & $\mathrm{X}$ & $\mathrm{X}$ & Aspredinidae & & & \\
\hline Moenkhausia oligolepis & Omnivorous & $\mathrm{X}$ & $\mathrm{X}$ & Bunocephalus coracoideus & Insectivorous & $\mathrm{X}$ & \\
\hline Moenkhausia sp. 2 & Omnivorous & $\mathrm{X}$ & $\mathrm{X}$ & Auchenipteridae & & & \\
\hline Moenkhausia sp. 5 & Omnivorous & & $\mathrm{X}$ & Trachelyopterus galeatus & Omnivorous & $\mathrm{X}$ & \\
\hline Odontostilbe sp. & Omnivorous & & $\mathrm{X}$ & Callichthyidae & & & \\
\hline Phenacogaster sp. & Insectivorous & $\mathrm{X}$ & $\mathrm{X}$ & Aspidoras sp. & Invertivore & $\mathrm{X}$ & $\mathrm{X}$ \\
\hline Poptella longipinnis & Omnivorous & $X$ & $\mathrm{X}$ & Corydoras sp. & Omnivorous & $X$ & $\mathrm{X}$ \\
\hline Psellogrammus sp. & Insectivorous & & $\mathrm{X}$ & Heptapteridae & & & \\
\hline Roeboxodon geryi & Lepidophagus & $\mathrm{X}$ & & Imparfinis sp. & Invertivore & $\mathrm{X}$ & $\mathrm{X}$ \\
\hline Serrapinnus cf. kriege & Omnivorous & $\mathrm{X}$ & & Pimelodella cristata & Omnivorous & $\mathrm{X}$ & \\
\hline Serrapinus sp. & Carnivorous & $\mathrm{X}$ & & Pimelodella sp. & Omnivorous & $\mathrm{X}$ & \\
\hline Tetragonopterus argenteus & Insectivorous & $X$ & & Rhamdella sp. & Invertivore & $\mathrm{X}$ & \\
\hline Tetragonopterus chalceus & Omnivorous & $X$ & & Loricariidae & & & \\
\hline Thayeria boehlkei & Omnivorous & $\mathrm{X}$ & & Hypostomus plecostomus & Detritivorous & $\mathrm{X}$ & $\mathrm{X}$ \\
\hline Ctenoluciidae & & & & Hypostomus sp. 1 & Detritivorous & $\mathrm{X}$ & $X$ \\
\hline Boulengerella cuvieri & Piscivorous & $\mathrm{X}$ & & Loricaria cataphracta & Omnivorous & $\mathrm{X}$ & $\mathrm{X}$ \\
\hline Curimatidae & & & & Otocincus tapirape & Algivorous & $\mathrm{X}$ & $\mathrm{X}$ \\
\hline Curimatella $\mathrm{sp}$. & Detritivorous & $X$ & & Rineloricaria $\mathrm{sp}$. & Algivorous & $\mathrm{X}$ & $\mathrm{X}$ \\
\hline Cyphocharax cf. spiluropsis & Detritivorous & $\mathrm{X}$ & & Trichomycteridae & & & \\
\hline & & & & Trichomycterus sp. & Invertivore & $\mathrm{X}$ & \\
\hline
\end{tabular}

Matthews and Robison 1998) spatial scales. In the present study, we demonstrated that patterns of taxonomic and functional richness of fish assemblages of two tropical neighbouring basins (Araguaia and Tocantins) responded differently to the size of the DA. A possible explanation for such differences is related to the percentage of natural cover observed in each basin. The upper section of the Araguaia and Tocantins River basins are both located in the cerrado, a biodiversity hotspot (Mittermeier et al. 2004, 2011). This biome is mainly threatened by the conversion of its original vegetation cover into areas for agriculture and cattle ranching (Klink and Machado 2005), implicating habitat loss and fragmentation, which are listed as major threats to fish diversity (Dudgeon et al. 2006).
The vegetation cover is not the same in both basins. There are many isolated or continuous areas of savanna shrub and shrubtree forests in the Tocantins basin, combined with a larger number of protected areas in its north-eastern region than in the Araguaia basin (Galinkin 2003). Streams with a low percentage of natural cover are probably affected by other environmental (e.g. water physicochemical characteristics) and landscape (e.g. presence of a floodplain area) factors than size area, which is the case for Araguaia River basin streams. However, a higher percentage of natural cover could mitigate the effects of agriculture and cattle-ranching, which is the case observed for Tocantins River basin streams, enabling a higher influence of the size of the DA. 
Table 3. Statistics of the multiple linear regression between the taxonomic richness of fish assemblages (S), functional richness and the factors drainage area (DA), algal biomass (AB) and organic matter (OM) of the watercourses sampled and grouped by basin Significant $(P<0.05) P$-values are in bold

\begin{tabular}{|c|c|c|c|c|}
\hline \multirow[t]{2}{*}{ Basin } & \multirow[t]{2}{*}{ Richness } & \multirow[t]{2}{*}{ Estimate } & \multicolumn{2}{|l|}{ Factor } \\
\hline & & & Area + available energy & Available energy \\
\hline \multirow[t]{6}{*}{ Araguaia } & \multirow[t]{3}{*}{ Taxonomic (S) } & $P$ & 0.618 & 0.391 \\
\hline & & $R^{2}$ & 0.213 & 0.209 \\
\hline & & & $\mathrm{S}=-19.6852+1.1964(\mathrm{DA})-0.4938(\mathrm{AB})+9.3619(\mathrm{OM})$ & $\mathrm{S}=-18.4216-0.5636(\mathrm{AB})+9.4468(\mathrm{OM})$ \\
\hline & \multirow{3}{*}{ Functional (SGT) } & $P$ & 0.957 & 0.862 \\
\hline & & $R^{2}$ & 0.041 & 0.036 \\
\hline & & & $\mathrm{SGT}=0.8193-0.2930(\mathrm{DA})+0.1526(\mathrm{AB})+0.9597(\mathrm{OM})$ & $\mathrm{SGT}=0.5098+0.1697(\mathrm{AB})+0.9389(\mathrm{OM})$ \\
\hline \multirow[t]{6}{*}{ Tocantins } & \multirow[t]{3}{*}{ Taxonomic (S) } & $P$ & 0.007 & 0.023 \\
\hline & & $R^{2}$ & 0.848 & 0.659 \\
\hline & & & $\mathrm{S}=-19.1060+4.2590(\mathrm{DA})-3.1201(\mathrm{AB})+7.8388(\mathrm{OM})$ & $\mathrm{S}=-5.6270-2.0342(\mathrm{AB})$ \\
\hline & \multirow[t]{3}{*}{ Functional (SGT) } & $P$ & 0.065 & 0.023 \\
\hline & & $R^{2}$ & 0.675 & 0.658 \\
\hline & & & $\mathrm{SGT}=-8.2386+0.5471(\mathrm{DA})-0.7609(\mathrm{AB})+3.6429(\mathrm{OM})$ & $\mathrm{SGT}=-6.5071-0.6215(\mathrm{AB})+3.2932(\mathrm{OM})$ \\
\hline
\end{tabular}

Table 4. Statistics of the total percentage of vegetation cover (TPVC, continuous predictor) by basin (categorical predictor) and results of the ANCOVA analysis between the residuals of the significant relationships, resulting from multiple linear regression (dependent variable), and the covariates (basin and TPVC)

Significant $P$-values are in bold $(P<0.05)$. S, taxonomic richness; SGT, functional richness

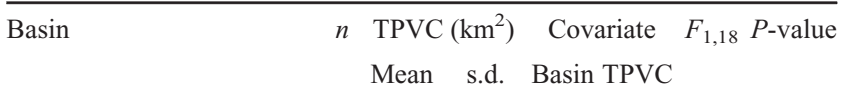

Araguaia

1116.04223 .575

Tocantins $\quad 1040.59029 .283$

Residual of the relationship:

$\mathrm{S} v$. area + available energy

$\mathrm{S} v$. available energy

SGT $v$. available energy

$\begin{array}{llll}0.089 & 0.287 & 3.228 & 0.089\end{array}$

$\begin{array}{llll}0.169 & \mathbf{0 . 0 1 3} & 2.057 & 0.169\end{array}$

$\begin{array}{llll}0.369 & 0.100 & 0.850 & 0.369\end{array}$

Moreover, removal of natural cover, including riparian vegetation, may influence the occurrence of species, because it hampers the input of allochthonous nutrients in the freshwater system (Vannote et al. 1980). This fact can partially explain the results found for the Araguaia River and in an opposite manner in the Tocantins basin (increase of taxonomic and functional richness along with the $\mathrm{OM}$ ). However, the vegetal cover in the Tocantins basin is not continuous, but interspersed with areas where the riparian vegetation is absent. This situation favours the entry of luminosity into the water column, promoting the rise of algae (Giller and Malmqvist 2000) and, consequently, the primary productivity in the aquatic system measured by the chlorophyll- $a$ (Barroso and Littlepage 1998), as was observed in the present study. Thus, the positive relationship between available energy and taxonomic and functional richness in Tocantins streams indicated that the input of nutrients into the system by the vegetation cover is capable of increasing the number of species and the number of species with different trophic habits in the system, but only when $\mathrm{AB}$ and $\mathrm{OM}$ are evaluated together. When these two components are evaluated separately, it is observed that an increase in $\mathrm{AB}$ has negative effects on taxonomic richness. This result suggests that the fish$\mathrm{AB}$ relationship observed in the Tocantins basin works similarly to the eutrophication phenomenon on fish diversity; that is, it causes changes to the fish assemblage composition or displacement, or elimination of fish populations (Lévêque et al. 2008).

An additional explanation for the different relationships of the fish assemblages from the two basins with area and available energy is the basin interconnection. In the present study, this was represented by the interconnection between the "Vereda Grande' stream (Tocantins basin) and 'Brejinho' stream (Paraná basin; Pavanelli and Britski 1999). These authors stated that this interconnection allows the exchange of fish species between these basins; thus, it influences on taxonomic and functional richness, both of which were measured in the present study.

The mentioned differences can be also related to regional and local characteristics of the habitat, such as the physicochemical characteristics of the water. The Araguaia is classified as a clear-water river and the Tocantins as a white-water one (Ríos-Villamizar et al. 2014). The type of water results from basin geochemistry that influences the isotopic composition of basal production (Jepsen and Winemiller 2007) and, in consequence, the type of available energy for aquatic biota including fish assemblages. Additionally, the Araguaia basin includes a floodplain that provides a greater number of shelters and food for fishes (Agostinho and Zalewski 1995; Junk 1997), increasing taxonomic fish richness (Tanaka et al. 2015) and the diversity of morphological, physiological and ethological attributes of species (Junk et al. 1989; Lowe-McConnell 1999). This could explain the elevated number of species observed in this basin in relation to Tocantins basin. However, some limitations of the present study are necessary to consider; one is related to the number of sampling points and the second to the period of sampling (low-water period). We believe that the sampling effort in the present study was appropriate to give us a first draft of these relationships in regions with little knowledge, and a good first look on how these relationships are structured in regional scales. However, increasing the number of unities and 


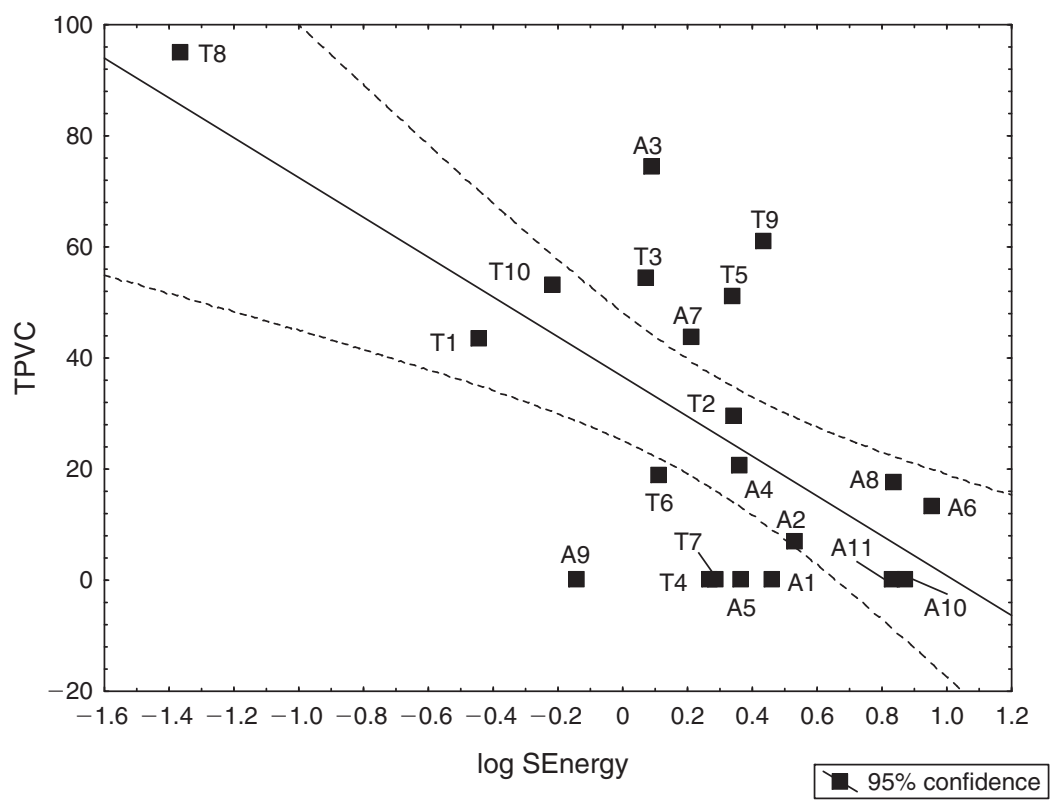

Fig. 2. Relation between the log of the residual of the taxonomic species-available energy relationship (log SEnergy) and the total percentage of the vegetation cover (TPVC) of the watercourses sampled (black squares). A, Araguaia; T, Tocantins.

the sampling effort for both dry and wet seasons in future studies may provide a better picture of the relationships between fish assemblages and area and fish assemblages and energy across space and time.

Understanding how the size of the DA and the available energy may affect fish species and their spatial distribution is a cornerstone to fish community ecology. Here, we showed that fish assemblages of two tropical neighbouring basins responded differently to the size of the DA and, this fact may be a consequence of the presence or absence of natural vegetation cover around streams. In other words, impacts caused by human population, as a result of agriculture and cattle-ranching, on natural vegetation cover near streams may affect species occurrence. Moreover, we demonstrated that both taxonomic richness and functional richness of these fish assemblages were affected by available energy in the system, which may also be influenced by the degree of natural vegetation cover near streams. Considering that area and available-energy effects are directly dependent on the presence or absence of natural vegetation cover, it is important to develop conservation actions to protect this highly endangered hotspot.

\section{Acknowledgements}

We thank to the team of the Centro de Biologia Aquática (CBA), especially to: Waldeir Francisco de Menezes, Nicelly Braudes de Araújo, Tatiana Melo and Thiago Vieira for collection of field data. We are also grateful to researchers from Pontifícia Universidade Católica do Rio Grande do Sul for fish species identification and to the National Council of Technological and Scientific Development (CNPq) for the financial support given for the project (CNPq number 471283/2006-1).

\section{References}

Agostinho, A. A., and Zalewski, M. (1995). The dependence of fish community structure and dynamics on floodplain and riparian ecotone zone in Parana River, Brazil. Hydrobiologia 303, 141-148. doi:10.1007/ BF00034051

Albert, J. E., and Reis, R. E. (2011). Introduction to neotropical freshwaters. In 'Historical Biogeography of Neotropical Freshwater Fishes'. (Eds J. E. Albert and R. E. Reis.) pp. 3-19. (University of California Press: Berkeley, CA.)

Albrecht, M. P., and Pellegrini-Caramaschi, E. (2003). Feeding ecology of Leporinus taeniofasciatus (Characiformes: Anostomidae) before and after the installations of a hydroelectric plant in the upper Rio Tocantins, Brazil. Neotropical Ichthyology 1, 53-60. doi:10.1590/S167962252003000100006

Arrhenius, O. (1921). Species and area. Journal of Ecology 9, 95-99. doi: $10.2307 / 2255763$

Barroso, G. F., and Littlepage, J. (1998). 'Protocolo para Análise de Clorofila a e Feopigmentaçãopelo Método Fluorimétrico (Fluorimetro TD-700). Programa de Monitoramento Ambiental.' (UFES: Vitória, Brazil.)

Bistoni, M. A., and Hued, A. C. (2002). Patterns of fish species richness in rivers of the central region of Argentina. Brazilian Journal of Biology 62, 753-764. doi:10.1590/S1519-69842002000500004

Carvalho, R. A., and Tejerina-Garro, F. L. (2015). Environmental and spatial processes: what controls the functional structure of fish assemblages in tropical rivers and headwater streams? Ecology Freshwater Fish 24, 317-328. doi:10.1111/EFF.12152

Chittaro, P. M. (2002). Species-area relationships for coral reef fish assemblages of St Croix, US Virgin Islands. Marine Ecology (Berlin) 233, 253-261. doi:10.3354/MEPS233253

Costa, M. H., Botta, A., and Cardille, J. A. (2003). Effects of large scale changes in land cover on the discharge of the Tocantins River, southeastern Amazonia. Journal of Hydrology 283, 206-217. doi:10.1016/ S0022-1694(03)00267-1

de Oliveira, I. J. (2014). Chapadões descerrados: relações entre vegetação, relevo e uso das terras em Goiás. Boletim Goiano de Geografia 34, 311-336.

Dudgeon, D., Arthington, A. H., Gessner, M. O., Kawabata, Z. -I., Knowler, D. J., Lévêque, C., Naiman, R. J., Prieur-Richard, A. -H., Soto, D., Stiassny, M. L. J., and Sullivan, C. A. (2006). Freshwater biodiversity: importance, threats, status and conservation challenges. Biological 
Reviews of the Cambridge Philosophical Society 81, 163-182. doi:10.1017/S1464793105006950

Eadie, J. McA., Hurly, T. A., Montgomerie, R. D., and Teather, K. L. (1986) Lakes and rivers as islands: species-area relationships in the fish faunas of Ontario. Environmental Biology of Fishes 15, 81-89. doi:10.1007/ BF00005423

Fialho, A. P., Oliveira, L. G., Tejerina-Garro, F. L., and Gomes, L. C. (2007) Fish assemblage structure in tributaries of the Meia Ponte River, Goiás, Brazil. Neotropical Ichthyology 5, 53-60. doi:10.1590/S167962252007000100007

Galinkin, M. (2003). 'GeoGoiás2002.' (Agência Ambiental de Goiás, Fundação CEBRAC, PNUMA, SEMARH: Goiânia, Brazil.)

Giller, P. S., and Malmqvist, B. (2000). 'The Biology of Streams and Rivers.' (Oxford University Press: New York.)

Guégan, J. F., Lek, S., and Oberdoff, T. (1998). Energy availability and habitat heterogeneity predict global riverine fish diversity. Nature $\mathbf{3 9 1}$, 382-384. doi:10.1038/34899

Hoeinghaus, D. J., Winemiller, K. O., and Taphorn, D. C. (2004). Compositional change in fish assemblages along the Andean piedmont-Llanos floodplaing gradient of the Portuguesa River, Venezuela. Neotropical Ichthyology 2, 85-92. doi:10.1590/S1679-62252004000200005

Jepsen, D. B., and Winemiller, K. O. (2007). Basin geochemistry and isotopic ratios of fishes and basal production sources in four neotropical rivers. Ecology Freshwater Fish 16, 267-281. doi:10.1111/J.1600-0633. 2006.00218.X

Junk, W. J. (1997). 'The Central Amazon Floodplain: Ecology of a Pulsing System.’ (Springer: Berlin.)

Junk, W. J., Bayley, P. B., and Sparks, R. E. (1989). The flood pulse concept in river-floodplain systems. In 'Proceedings of the International Large River Symposium (LARS)’, 14-21 September 1986, Honey Harbour, ON, Canada. (Ed. D. P. Dodge.) Canadian Special Publication of Fisheries and Aquatic Sciences 106, pp. 110-127. (Canadian Government Publishing Centre: Ottawa, ON, Canada.) Available at http://www. dfo-mpo.gc.ca/Library/111846.pdf [Verified 7 June 2016].

Klink, C. A., and Machado, R. B. (2005). Conservation of the Brazilian cerrado. Conservation Biology 19, 707-713. doi:10.1111/J.1523-1739. 2005.00702.X

Lévêque, C., Oberdorff, T., Paugy, D., Stiassny, M. L. J., and Tedesco, P. A. (2008). Global diversity of fish (Pisces) in freshwater. Hydrobiologia 595, 545-567. doi:10.1007/S10750-007-9034-0

Losos, J. B., and Schluter, D. (2000). Analysis of an evolutionary speciesarea relationship. Nature 408, 847-850. doi:10.1038/35048558

Lowe-McConnell, R. H. (1999) 'Estudos Ecológicosde Comunidadesde Peixes.' (Edusp: São Paulo, Brazil.)

MacArthur, R. H., and Wilson, E. O. (1967). 'The Theory of Island Biogeography.' (Princeton University Press: Princeton, NJ, USA.)

Matthews, W. J., and Robison, H. W. (1998). Influence of drainage connectivity, drainage area and regional species richness on fishes of the interior highlands in Arkansas. American Midland Naturalist 139 , 1-19. doi:10.1674/0003-0031(1998)139[0001:IODCDA]2.0.CO;2

Melo, C. E., Lima, J. D., Pinto-Silva, V., and Melo, T. L. (2005). 'Peixes do Rio das Mortes: Identificação e Ecologia das Espécies Mais Comuns.' (Editora UNEMAT: Cáceres, Brazil.)

Mittermeier, R. A., Gil, P. R., Hoffman, M., Pilgrim, J., Brooks, T., Mittermeier, C. G., Lamoreux, J., Fonseca, G. A. B., Seligmann, P. A., and Ford, H. (2004). 'Hotspots Revisited: Earth's Biologically Richest and Most Endangered Ecoregions.' (CEMEX: Mexico City)

Mittermeier, R. A., Turner, W. R., Larsen, F. W., Brooks, T. M., and Gascon, C. (2011) Global biodiversity conservation: the critical role of hotspots. In 'Biodiversity Hotspots: Distribution and Protection of Conservation Priority Areas'. (Eds F. E. Zachos and J. C. Habel.) pp. 3-22. (Springer: Berlin.)

Pavanelli, C. S., and Britski, H. A. (1999). Description of a new species of Steindachnerina (Teleostei: Characiformes: Curimatidae) from the upper Rio Paraná basin, Brazil. Ichthyological Exploration of Freshwaters 10, 211-216.

Planquette, P., Keith, P., and Le Bail, P. -Y. (1996). 'Atlas des Poissons d'Eau Douce de Guyane.' (Collection du Patrimoine Naturel: Paris.)

PMDBBS (2016). Projeto de Monitoramento do Desmatamento dos Biomas Brasileiros por Satélite. Available at http://www.mma.gov.br/images/ arquivo/80120/PPCerrado/Relatorio\%20Tecnico_Bioma\%20Cerrado_ 2011vfinal.pdf [Verified 23 March 2016].

Quesada, C. A., Miranda, A. C., Hodnett, M. G., Santos, A. J. B., Miranda, H. S., and Breyer, L. M. (2004). Seasonal and depth variation of soil moisture in a burned open savanna (campo sujo) in central Brazil. Ecological Applications 14, 33-41. doi:10.1890/01-6017

Reis, R. E., Kullander, S. O., and Ferrari, C. J. Jr (2003). 'Check List of the Freshwater Fishes of South and Central America.' (EDPUCRS: Porto Alegre, Brazil.)

Ribeiro, M. C. L. B., Petrere, M. Jr, and Juras, A. A. (1995). Ecological integrity and fisheries ecology of the Araguaia-Tocantins River Basin, Brazil. Regulated Rivers: Research and Management 11, 325-350. doi:10.1002/RRR.3450110308

Ríos-Villamizar, E. A., Piedade, M. T. F., Da Costa, J. G., Adeney, J. M., and Junk, W. J. (2014). Chemistry of different Amazonian water types for river classification: a preliminary review. War \& Society III 78, 17-28.

Santana, A. O., Tejerina-Garro, F. L., and Carvalho, R. A. (2014). Variação da diversidade $\alpha$ e $\beta$ das assembleias de peixes num gradiente montantejusante em um rio tropical, Brasil central. Fronteiras Sociedade Tecnologia e Meio Ambiente 3, 106-118. doi:10.21664/2238-8869. 2014V3I1.P106-118

Santos, G. M., Mérona, B., Juras, A. A., and Jégu, M. (2004). 'Peixes do Baixo Rio Tocantins: 20 Anos Depois da Usina Hidrelétrica Tucuruí.' (Eletronorte: Brasília, Brazil.)

Silva, A. C., Torrado, P. V., and Abreu, J. S. Jr (1999). Métodos de quantificação da matéria orgânica do solo. Revista Universidade de Alfenas 5, 21-26.

Strahler, A. N. (1957). Quantitative analyses of watershed geomorphology. Transactions - American Geophysical Union 38, 913-920. doi:10.1029/ TR038I006P00913

Strayer, D. L., and Dudgeon, D. (2010). Freshwater biodiversity conservation: recent progress and future challenges. Journal of the North American Benthological Society 29, 344-358. doi:10.1899/08-171.1

Súarez, Y. R., Souza, M. M., Ferreira, F. S., Pereira, M. J., Silva, E. A., Ximenes, L. Q. L., Azevedo, L. G., Martins, O. C., and Lima-Júnior, S. E. (2011). Patterns of species richness and composition of fish assemblages in streams of the Ivinhema River basin, Upper Paraná River. Acta Limnologica Brasiliensia 23, 177-188. doi:10.1590/S2179975X2011000200008

Tanaka, W., Wattanasiriserekul, R., Tomiyama, Y., Yamasita, T., Phinrub, W., Chamnivikaipong, T., Suvarnaraksha, A., and Shimatani, Y. (2015) Influence of floodplain area on fish species richness in waterbodies of the Chao Phraya River Basin, Thailand. Open Journal of Ecology 5 434-451. doi:10.4236/OJE.2015.59036

Tejerina-Garro, F. L. (2008) 'Biodiversidade e Impactos Ambientais no Estado de Goiás.' (Editora da UCG: Goiânia, Brazil.)

Teresa, F. B., Casatti, L., and Cianciaruso, M. V. (2015). Functional differentiation between fish assemblages from forested and deforested streams. Neotropical Ichthyology 13, 361-370. doi:10.1590/1982-022420130229

Vannote, R. R., Minshall, G. W., Cummins, K. W., Sedell, J. R., and Cushing, C. E. (1980). The river continuum concept. Canadian Journal of Fisheries and Aquatic Sciences 37, 130-137. doi:10.1139/ F80-017

Vörösmarty, C. J., Mcintyre, P. B., Gessner, M. O., Dudgeon, D., Prusevich, A., Green, P., Glidden, S., Bunn, S. E., Sullivan, C., Liermann, C. R., and Davies, P. M. (2010). Global threats to human water security and river biodiversity. Nature 467, 555-561. doi:10.1038/NATURE09440 
Watters, G. T. (1992). Unionids, fishes and the species-area curve. Journal of Biogeography 19, 481-490. doi:10.2307/2845767

Wetzel, R. G., and Likens, G. E. (1991). 'Limnological Analyses.' (Springer Verlag: New York.)

Whittaker, R. J., Willis, K. J., and Field, R. (2001). Scale and species richness: towards a general, hierarchical theory of species diversity. Journal of Biogeography 28, 453-470. doi:10.1046/J.1365-2699.2001. 00563.X
Williamson, M. (1988). Relationships of species number to area, distance and other variables. In 'Analytical Biogeography. An Integrated Approach to the Study of Animal and Plant Distributions'. (Eds A. A. Meyers and P. S. Giller.) pp. 91-115. (Chapman and Hall: London.)

Wright, D. H. (1983). Species-energy theory: an extension of species-area theory. Oikos 41, 496-506. doi:10.2307/3544109 